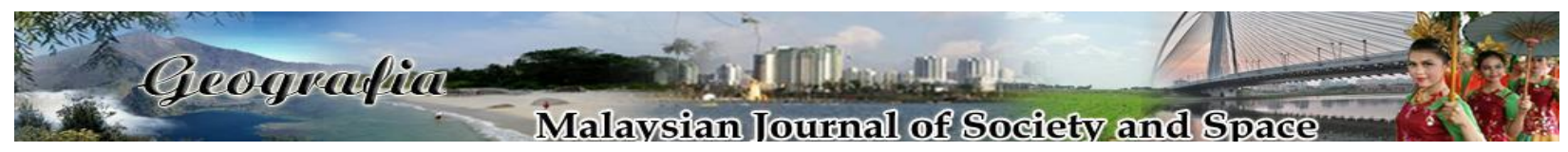

\title{
A resolution framework for post-implementation issues of urban regeneration projects in the city of Colombo, Sri Lanka
}

\author{
Y. M. P. Lavanya, W.H.T. Gunawardhana, M.T.U. Perera \\ Department of Estate Management and Valuation, \\ University of Sri Jayewardenepura, Sri Lanka
}

Correspondence: W.H.T. Gunawardhana (email: terans@sjp.ac.lk)

Received: 13 May 2021; Accepted: 02 August 2021; Published: 27 August 2021

\begin{abstract}
After the civil war, the Sri Lankan government started the urban regeneration initiative focusing on Colombo city development. These projects have proved to be just immediate solutions, with no long-term effect on the community. Thus, this study examined the post-implementation issues of the Colombo urban regeneration project to develop a resolution framework. Subsequently, the study applied three similar cases viz., the Pruitt-Igoe, Chennai, and Kibera to understand the lessons and similar issues of urban regeneration projects such as social and cultural, economic, architectural, planning, and technical and management and operational that supported to develop the resolution model. The empirical analysis was based on a mixed-method approach with perceptions of low-income dwellers and professionals. Hence, the study concludes that social, cultural, and economic issues are most critical in Sri Lankan, similar to the other Asian studies. However, the post-implementation impacts of urban regeneration on the quality of life of urban poor have only received marginal attention and fewer successive policies in Sri Lanka.
\end{abstract}

Keywords: Colombo, post-implementation issues, resolution framework, urban regeneration projects,

\section{Introduction}

Urban regeneration is a process that improves the economic, social, and environmental conditions in an area. Peter Roberts (2000) described regeneration as a "comprehensive and integrated vision and action which leads to the resolution of urban problems and seeks to bring about a lasting improvement in the economic, physical, social and environmental condition of an area that has been subject to change." The origin of the urban regeneration concept has a long history, and the causes and effects of regeneration projects are varied from country to country. Urban regeneration is a crucial element in European public policy that originated after the Second World War due to the characteristics of urban decay with dilapidated buildings in the cities. Later many European 
cities have had to cope with the decline of their principal industries, and many urban regeneration models were implemented and successful. Viz. Liverpool, Barcelona, Bilbao, Genoa, Rotterdam, La Mina, etc., were the most prestigious urban regeneration projects in European cities. The Asian cities, urban regeneration schemes vastly commenced around the deprived urban neighborhood regeneration and utility development in cities. For instance, Pakistan Cities of Lahore, Karachi, Sialkot, and Indian cities such as Kuniyamuthur: Delhi: Prayagraj: Mumbai: Bhubaneswar: Chandigarh: Ahmedabad: Jammu and Kashmir Colony were employing urban regeneration as the primary solution. The aim is to formalize and integrate the informal urban settlers in respective cities by providing a high-quality living environment, life opportunities, and social cohesion with the rest of the city. In Sri Lanka, the process of urban regeneration mainly originated based on the Colombo city development and focusing on improving housing conditions of low-income communities and increasing use efficiency through investments in affordable housing and the redevelopment of lands (UDA, 2019). Therefore, urban regeneration has become a key element in urban policy schemes that can reorganize unplanned urban environments and prevent undesirable slums and informal settlements by establishing high-rise, low-income housing development. (Wijayasinghe, 2010). Accordingly, urban regeneration projects always anticipated achieving sustainable outcomes from the development process worldwide.

Almost 10 million people are displaced due to development projects worldwide. Six million people are reportedly displaced from their lands and homes due to the urban regeneration process each year (Stanley, 2004). Thus, it records that most of the development-induced resettlement projects failed due to landlessness, joblessness, marginalization, isolation, and social disarticulation. Therefore, urban regeneration projects are more complicated and challenging due to the vast disputes and failures in the planning and implementation stages of the project. In this sense, the study aims to examine and analyze the post-implementation issues of urban regeneration projects in Sri Lanka to develop a resolution framework for identified issues. The study applies three similar cases viz., the Pruitt-Igoe, Chennai, and Kibera to understand the lessons and similar issues of urban regeneration such as social \& cultural, economic, architectural, planning \& technical and management \& operational that may support to develop the resolution model. The empirical analysis is based on quantitative and qualitative methods with awareness and perceptions of relocated low-income dwellers and views of professionals. The results demonstrate that there were no concrete processes early on this process. Understanding post-implementation issues are essential for informing urban planning theory and practices to determine the complexities and challenges of today's urban regeneration projects in achieving long-term sustainability.

\section{Literature review}

\section{Urban regeneration process in Sri Lanka}

After the civil war in 2009, many urban regeneration projects are initiated in Sri Lanka. Amongst Colombo urban regeneration projects is the largest urban renewal schemes which mainly initiated based on the Colombo city development and focusing the terms of "improving housing conditions of low-income communities and increase land-use efficiency in Colombo through investments in the construction of affordable housing and the redevelopment of land" (UDA, 2019). The origin of the area consists of informal settlements with overcrowded and unhealthier living conditions. The slums, shanties, underserved semi-urban neighborhoods, and labor lines or derelict living quarters are the four major categories of underserved settlements in Colombo. According to the 
UDA preliminary survey, approximately 66000 informal families were clustering in 900 acres of potential lands in Colombo. Therefore, the Government of Sri Lanka (GoSL) must change the undesirable and unplanned living conditions as more productive due to locational significance and advantages in Colombo, Sri Lanka.

Since 2014, the Urban Development Authority (UDA) has constructed 4937 low-income housing units under ten re-settlement schemes in various parts of Colombo and handed them over to the public as part of the first stage of urban regeneration viz., i.Mihindusen Pura ii. Puradora Sewana iii. Lakmuthu Sewana iv.Sirisada Sewana v.Sirisara Uyana vi. Methsara Uyana vii. Randiya Uyana viii. Sirimuthu Uyana ix. Laksada Sewana and x. Muwadora Uyana. So far, these projects were conducted with comprehensive prior assessments of environmental, social, economic, financial, legal, etc. Even though the high-rise development in the resettlement process is an empathetic experience for low-income people, it adversely affected their lives with several issues after the project implementation. At the same time, housing professionals and urban planners in Sri Lanka have mixed emotions towards Colombo's high-rise, low-income housing adoption. The principal impediment in the field is a lack of literature and study. Colombo City requires further academic research to determine the critical factors in the success or failure of lowincome housing, especially high-rise, low-income housing. About the fact that high-rise, lowincome housing is a novel concept for Sri Lanka, but not new in many other countries. Therefore, foreign experience and objective assessment of previous experiences will be beneficial to evaluate the post-implementation issues of Sri Lankan high-rise low-income housing projects that belong to the urban regeneration to develop the resolution model.

The Pruitt-Igoe affordable housing complex in St. Louis, Missouri, is one of the most verbose public housing developments in the United States and a symbolic landmark and the most well-known case study resulting in removing 2,800 housing units. Subsequently, the Perumbakkam Tenements in Chennai, India, is a prestigious low-income housing project that built 20,376 housing units and handed over to the public since 2014. Thus, Kibera is one of Africa's largest slums, with a population of 400,000. The urban regeneration was completed 822 housing units for low-income communities and turned over to them since 2016. Accordingly, the PruittIgoe, Chennai, and Kibera cases are similar to the Colombo high-rise low-income housing scheme allied to the relocation of underserved settlements and all housing projects aimed to eliminate slums by supplying high-rise housing for the urban poor. Therefore, understanding these three similar foreign experiences is essential to identify this context to minimize risk and avoid making the same mistakes while designing high-rise, low-income housing in the country.

In essentially scrutinizing the Pruitt-Igoe, Chennai, and Kibera projects, as well as other notable high-rise low-income housing projects, it becomes apparent that the majority of problems fall into four categories viz., Social and cultural issues (Mullins, et al., 2001; Soureshjani \& Soureshjani, 2016), Architectural, planning and technical issues (Bah, et al., 2018), Financial issues (Calderon, 2008; Average, 2019); and management and operational issues (Kolodny, et al., 1983; Tilabi, et al., 2017).

To better understand the problems around high-rise low-income housing, an in-depth analysis of the Pruitt-Igoe, Chennai, and Kibera housing schemes (Figure 1-4) should be conducted to compare social and cultural issues, architectural design and technological issues, financial issues, and management and organizational issues that impacted these projects. 


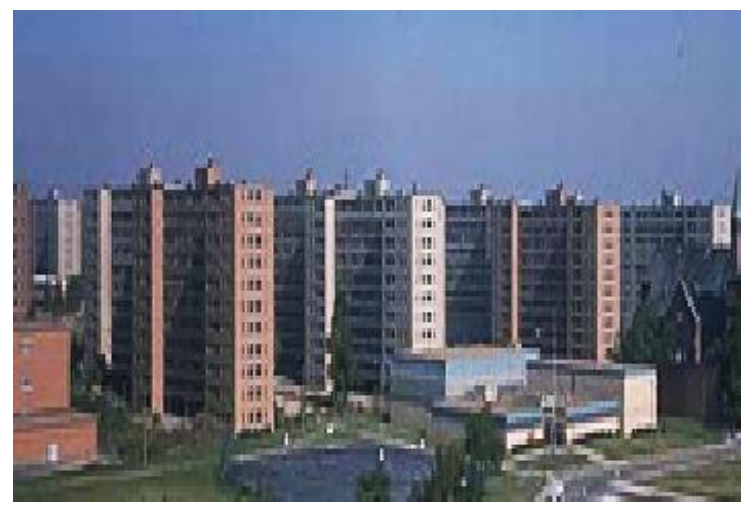

Source:https://www.theguardian.com/cities/2015/a $\mathrm{pr} / 22 /$ pruitt-igoe-high-rise-urban-america-historycities

Figure 1. Pruitt-Igoe High-Rise Housing Project



Source:https://nairobinews.nation.co.ke/news/kibera -get-3000-houses-slum-upgrading-project

Figure 3. Kibera Low Income Housing Project

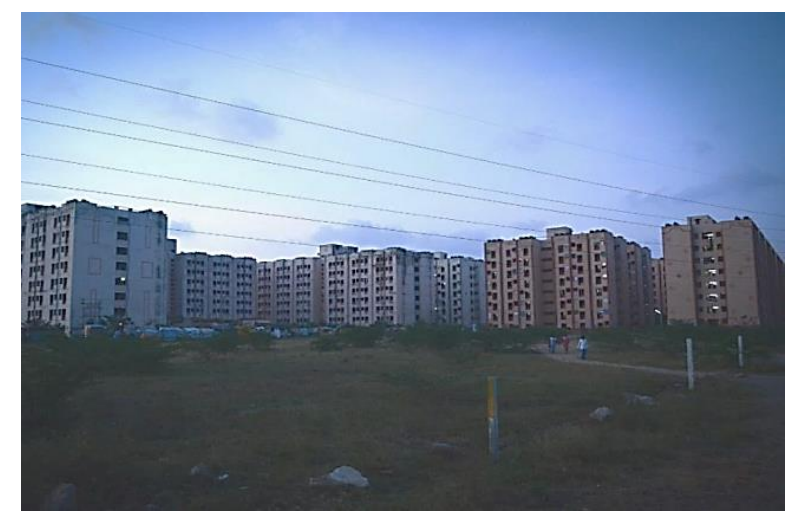

Source:https://thefederal.com/states/south/tamilnadu/di stanced-from-the-city-slum-dwellers-in-chennai-facestark-reality/

Figure 2. Chennai High-Rise Slum Housing Project

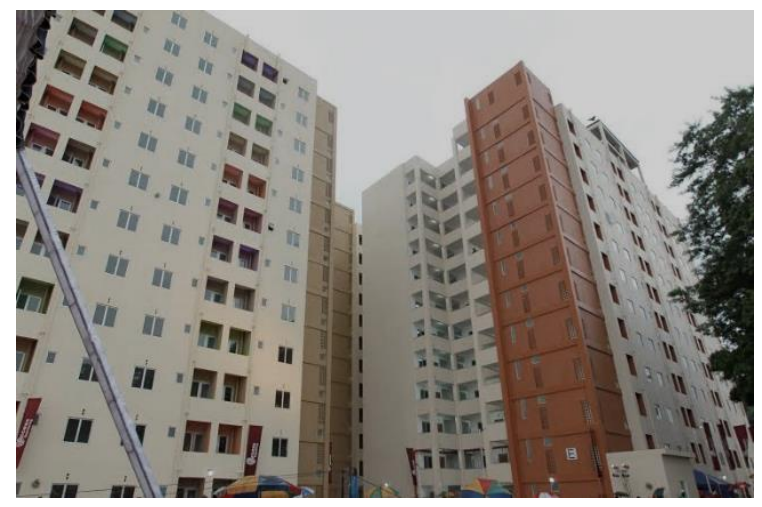

Source:https://www.news.lk/news/politics/item/4464randiya-uyana-housing-scheme-declared-openmarking-president-s-b-day

Figure 4. Colombo Low Income Housing Project

\section{Method and study area}

The study aims to identify the post-implementation issues to build a resolution framework for an urban regeneration project in Colombo. Based on this aim, the conceptual framework is framed, which is presented in figure 5. The primary post-implementation issues of the three similar high rise low-income housing to build a resolution framework is shown in Table 1. 


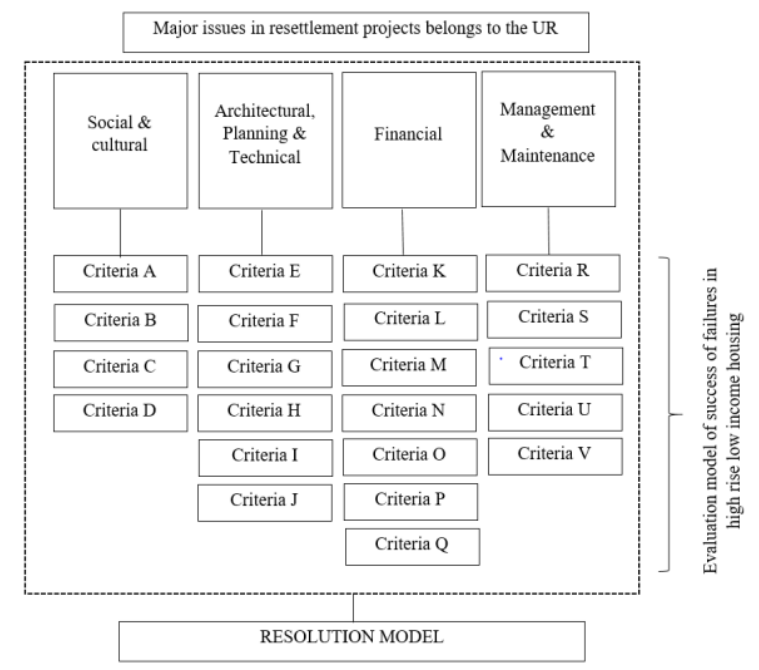

Figure 5. Conceptual framework.

Table 1. The primary post-implementation issues of three similar high rise low-income housing.

\begin{tabular}{|c|c|c|c|c|}
\hline & Criteria & Pruitt-Igoe & Chennai & Kibera \\
\hline \multicolumn{5}{|c|}{ Social and cultural } \\
\hline A & $\begin{array}{l}\text { Information flows and educational } \\
\text { attainment. }\end{array}$ & Not mentioned & High (---) & High (---) \\
\hline B & Gentrification and social exclusion & medium (--) & High(---) & $\operatorname{High}(---)$ \\
\hline $\mathrm{C}$ & $\begin{array}{l}\text { Identity, well-being, and community } \\
\text { groups networking }\end{array}$ & High (---) & High(---) & High(---) \\
\hline $\mathrm{D}$ & Security, privacy and crimes & High (---) & High(---) & High (---) \\
\hline \multicolumn{5}{|c|}{ Economic } \\
\hline $\mathrm{E}$ & Employment opportunities & Moderate (--) & $\operatorname{High}(---)$ & High (---) \\
\hline $\mathrm{F}$ & Transport cost & Moderate (--) & High(---) & High (---) \\
\hline G & Financial security and loan facility & High (---) & High (---) & High (---) \\
\hline $\mathrm{H}$ & Monthly rent & High (---) & High (---) & High (---) \\
\hline I & Monthly bills & High (---) & High (---) & High(---) \\
\hline $\mathrm{J}$ & Other assets & Moderate (--) & High (---) & High (---) \\
\hline \multicolumn{5}{|c|}{ Architectural, planning, and technical } \\
\hline $\mathrm{K}$ & Quality housing design & High (---) & High (---) & High (---) \\
\hline $\mathrm{L}$ & Number of rooms & High (---) & High (---) & Moderate (--) \\
\hline M & Floor area & High (---) & Moderate (--) & High(---) \\
\hline $\mathrm{N}$ & Recreational and landscaping & High (---) & Moderate (--) & Moderate (--) \\
\hline $\mathrm{O}$ & Location of new housing & Low $(+)$ & High(---) & High (---) \\
\hline $\mathrm{P}$ & Elevator designs & High (---) & Moderate (--) & Not mentioned \\
\hline Q & Expansion the unit & High (---) & High(---) & High (---) \\
\hline \multicolumn{5}{|c|}{ Management and operational } \\
\hline $\mathrm{R}$ & Public spaces & High (---) & Moderate(--) & High(---) \\
\hline $\mathrm{S}$ & Electricity and water networks & High (---) & High(---) & High(---) \\
\hline $\mathrm{T}$ & Solid waste & Not mentioned & Moderate (--) & High (---) \\
\hline $\mathrm{U}$ & Corridors and Elevators & High (---) & $\operatorname{High}(---)$ & Moderate (--) \\
\hline $\mathrm{V}$ & Cost of management of entire building & High (---) & High(---) & Moderate (--) \\
\hline
\end{tabular}

Sources: Pruitt-Igoe: (Bristol, 1991; O'Neil, 2007; Samaratunga \& Hare, 2012)

Chennai: ( Jayaseelan \& Premraj, 2014; Diwakar \& Peter, 2016)

Kibera : (Amnesty International, 2009; Mitra, et al., 2017; Fernandez \& Calas, 2019)

Note: the way of the effects: , (+) shows a positive direction, and , (-) shows a negative direction; the intensity of the impacts: , $(+/-)$ shows low impact, $(++/--)$ shows the medium impact and (+++/-- $)$ shows high impact 


\section{Study area}

The projects that included the first phase in Colombo urban regeneration were chosen because they can recognize the actual condition of projects handed over to the community over a long time. Among the ten projects, Randiya Uyana low-income housing Project has been selected to investigate the study further. Randiya Uyana is located in Henamulla, Modara GN division in Colombo (Figure 6). It comprises 1137 housing units in 5 housing blocks. The total land area is $17,500 \mathrm{~m}^{2}$.

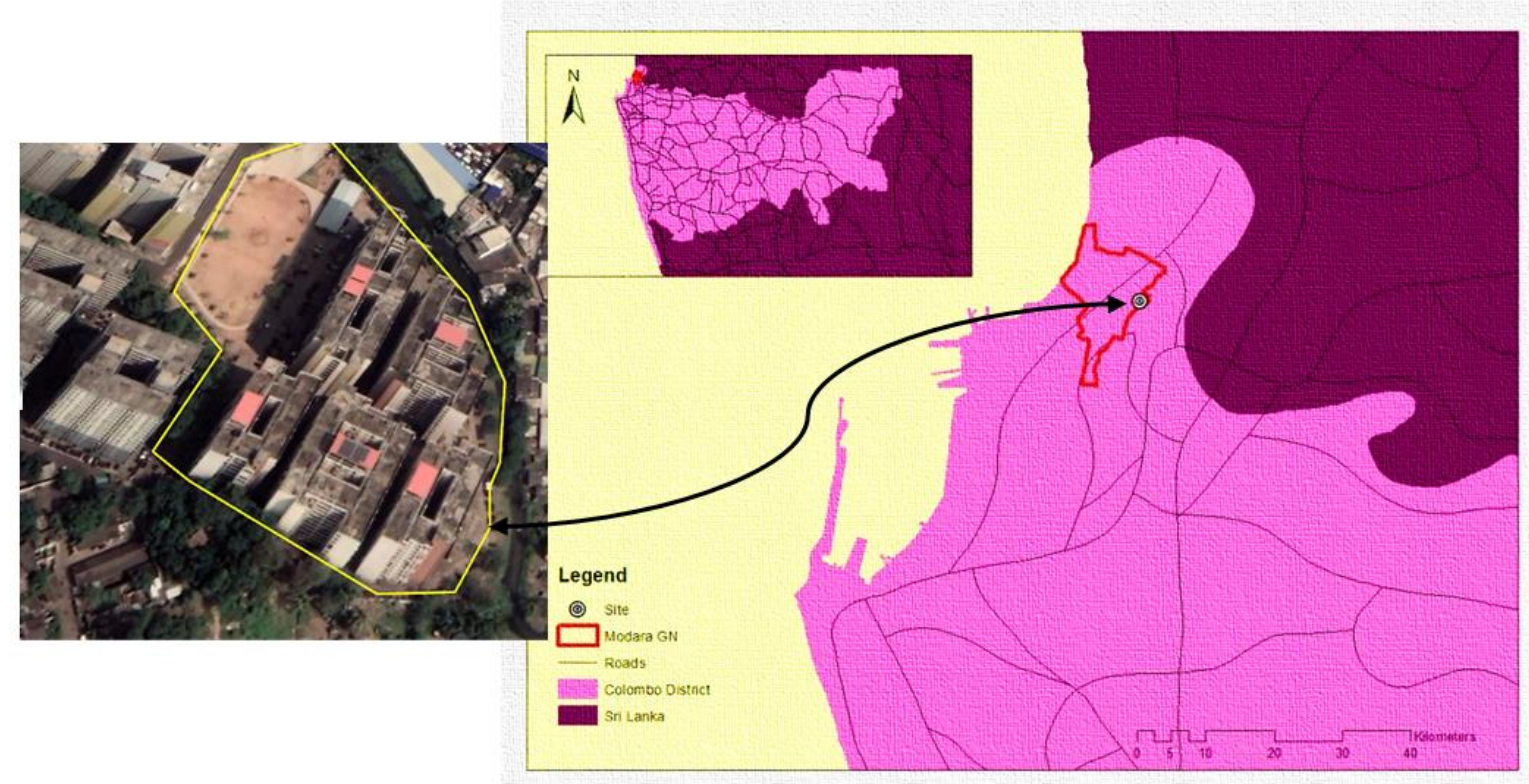

Source: Department of Survey Sri Lanka

Figure 6. Location of the study site.

\section{Data collection and analysis}

The data is attained from primary and secondary sources. The study's empirical data contains ten semi-structured interviews with key stakeholders involved in the case study project. The professional interviewees were selected based on their professional and personal experiences (more than 15 years) on re-settlement projects using the judgmental sampling method (Table 2). The interviews were carried out at the end of 2020, and interview questions were mainly directed to find solutions for architectural planning and technical issues and management and maintenance issues.

Residents were selected from the case-study neighborhoods to carry out the questionnaire survey. Two hundred respondents of resettled families were selected to identify the postimplementation issues of the selected project. The purposive sampling method is adopted to select the sample from resettled families in the Randiya Uyana re-settlement project. Thus the main attributes of respondents to be representative from the age and gender groups, main ethnic categories (Sinhalese, Tamil, Muslims, and Burghers), family size, socio-economic categories, educational level, and their previous residential location (Table 3). 
Field observation is used to identify the details of the physical aspects of re-settlers. They relied more on secondary data collected through documentary reviews since it is the only possible option to identify background information, issues, and global practices of urban regeneration and re-settlement procedures. The gathered data was tabulated in excel format, and analysis was done using statistical and graphical analysis.

Table 2. Profile of the semi-structural interview respondents.

\begin{tabular}{ccccc}
\hline Respondent & Designation & Experience & Working Sector & Awareness of the approach \\
\hline $\mathbf{A}$ & Enforcement Officer & 17 Years & Public & Well aware \\
$\mathbf{B}$ & Financial Manager & 15 Years & Public & Well aware \\
$\mathbf{C}$ & Architect & 25 Years & Private \& Public & Well aware \\
$\mathbf{D}$ & Client Representative & 23 Years & Private \& Public & Well Aware \\
$\mathbf{E}$ & Urban Planner & 20 Years & Public & Well aware \\
$\mathbf{F}$ & Enforcement Officer & 18 Years & Public & Well aware \\
$\mathbf{G}$ & Real Estate Manager & 25 Years & Public & Well aware \\
$\mathbf{H}$ & Urban Planner & 17 Years & Public & Well aware \\
$\mathbf{I}$ & Urban Planner & 26 Years & Public & Well aware \\
$\mathbf{J}$ & Regeneration Manager & 19 Years & Public & Well aware \\
\hline
\end{tabular}

Source: Survey Data, 2021

Table 3. Profile of the questionnaire survey respondents.

\begin{tabular}{|c|c|c|c|}
\hline Attributes & Percentage & Attributes & Percentage \\
\hline Gender & & \multicolumn{2}{|c|}{ Previous Residential Location } \\
\hline Male & $112(56 \%)$ & 318 Watta & $33(16.5 \%)$ \\
\hline Female & $88(44 \%)$ & Madampitiya & $22(11 \%)$ \\
\hline Age Category & & Henamulla & $52(26 \%)$ \\
\hline Below 30 Years & $64(32 \%)$ & Nagalam Weediya & $8(4 \%)$ \\
\hline $30-50$ Years & $75(37.5 \%)$ & 219 Watta & $16(8 \%)$ \\
\hline Above 50 years & $61(30.5 \%)$ & Welskumara Road & $7(3.5 \%)$ \\
\hline Ethnicity & & 225 Watta & $15(7.5 \%)$ \\
\hline Sinhalese & $84(42 \%)$ & 484 Watta & $19(9.5 \%)$ \\
\hline Tamil & $33(16.5 \%)$ & Maligakanda White Path & $7(3.5 \%)$ \\
\hline Muslim & $36(18 \%)$ & Furguson Road camp & $5(2.5 \%)$ \\
\hline Burghers & $35(17.5 \%)$ & Bosewana Watta & $6(3 \%)$ \\
\hline Other & $12(6 \%)$ & Apple Watta & $6(3 \%)$ \\
\hline Family Size & & Offices & $1(0.5 \%)$ \\
\hline$>4$ & $32(16 \%)$ & Other Places & $3(1.5 \%)$ \\
\hline $5-8$ & $89(44.5 \%)$ & & \\
\hline$<8$ & $79(39.5 \%)$ & & \\
\hline \multicolumn{4}{|l|}{ Educational Level } \\
\hline No Schooling & $24(12 \%)$ & & \\
\hline Primary Level & $118(56 \%)$ & & \\
\hline Ordinary Level & $45(22.5 \%)$ & & \\
\hline Advanced Level & $13(6.5 \%)$ & & \\
\hline \multicolumn{4}{|c|}{ Income Level (Monthly) } \\
\hline$>15000$ & $154(77 \%)$ & & \\
\hline $15000-45000$ & $41(20.5 \%$ & & \\
\hline$<45000$ & $5(2.5 \%)$ & & \\
\hline
\end{tabular}

Source: Survey Data, 2021 


\section{Results and discussion}

\section{Social issues}

The study demonstrates that security, privacy, and crimes are severe social problems in lowincome housing development projects. It is presented in figure 7 as $87.5 \%$. The crime statistics indicate that drug violations and severe property offenses such as burglary, larceny, and motor vehicle theft in the Randiya Uyana housing development increased by $35 \%$ and $20 \%$, respectively, annually from 2015 to 2020 . This prevalence is far higher for the same types of crimes than citywide and surrounding low-income community averages. Thus, it directly impacted on security and privacy of the residents, especially for women and children in these housing units. Subsequently, one of the most debated facets of low-income regeneration schemes has been identity well-being and the development of spaces for community grouping networking, thereby enriching urban life; however, the efficacy of these efforts has also been contested. It presented as a $78 \%$ second-highest rate during the critical social issue in Randiya Uyana low-income community. As per their interpretations, households were granted no paperwork on their apartment and were instead given an allotment letter stating that they were not permitted to rent, mortgage, or sell the apartment until they had paid the one million rupees while despite being required to sign several documents, communities were not given a copy of any of the documents they were requested to sign.

Additionally, documents were only available in Sinhala, and translations were not made available to Tamil communities. These disputes caused to reduce the identity and well-being of the low-income communities. Hence, the majority of the responders were people who had extended occupancy at the same place. Therefore, most of the nearby persons were relatives or friends of theirs. Given the data, $65 \%$ of the occupants were in the habit of visiting their relatives/friend's places. Therefore, they had a strong relationship with neighbors within the neighborhood at their original settlement. In this sense, they have vanished their community networking with the new re-settlement project.

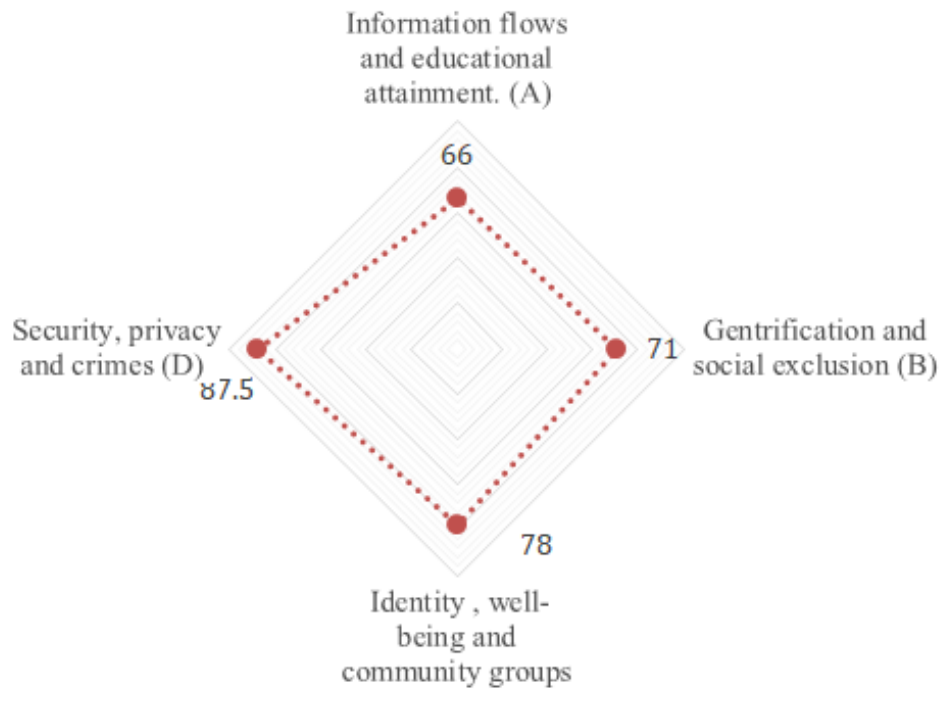

Source: Survey Data, 2021

Figure 7. Nature of the social issues in resettlement housing. 
Another main social problem confronting the low-income population is gentrification and social exclusion. Knowledge of the literature review and comments and responses from the questionnaire is linked to the concepts of gentrification and social exclusion in order displacement, accounting for $71 \%$ of the total. The new economic condition and middle-class gentry's arrival in these neighborhoods forced them to leave and displace new housing. Finally, information flows and educational attainment have become a severe cause for the Randiya Uyana low-income residents, representing $66 \%$ in figure 7 . Currently, they have no proper information flow about the project site and restrictions to the schools' pre-school.

\section{Economic issues}

As revealed in the survey with the local civic community, the Randiya Uyana project faces economic disputes. Mainly problems on employment opportunities which presented as $90 \%$ in figure 8. Most of the respondents were involved in informal businesses, while 13 of the 200 surveyed were employed on waged employment since their previous location. Amongst $90 \%$ of responses are currently inclining employment disputes due to misplacing their previous businesses. For instance, in the previous settlements, several families had home-based businesses. Some of them made food from their homes and had their own buyers' bases in the areas where they set up small boutiques and stalls. Some of them supplied food to various canteens, while others had small hotels that bought things from them such as sweets, hoppers, etc. however, all the businesses are lost due to the new settlement living. As well as due to the new vertical living, the residents who owned carpentry and welding shops were stopped by the limited amount of space available while missing parking places for three-wheel hiring and challenging to access cleaning and other sanitary work, etc. Accordingly, the average daily income was 1000-2000, and now it became zero for half of them. Therefore they cannot afford the high living cost of the Colombo city area.

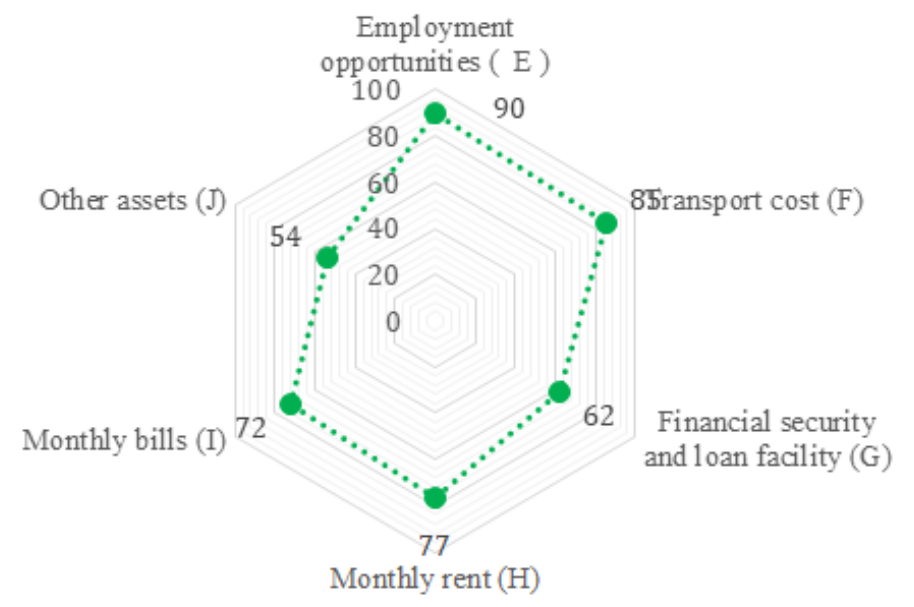

Source: Survey data, 2021

Figure 8. Nature of the economic issues in re-settlement housing.

Children can walk to school at their original location, and adults can easily access their daily basic requirements, including the relocation process that has tripled their transportation costs. This was a severe issue them while it indicated from $85 \%$ response rate. So far, with the new high rise living, people have to afford unanticipated expenses for their houses viz., monthly rent and monthly bills for electricity and water supply which presented as $77 \%$ and $72 \%$ respectively. 
According to the UDA, each apartment is valued at seven million rupees and is given away for one million rupees. To take possession of the apartment, people have to pay a monthly rent of Rs.5600.00 over 30 years; this is a substantial financial burden for many low-income families, particularly when they often lose the money they invested in their former homes and are not paid for it. In addition, utility bills such as water and electricity were not issued once a month, but once every two months or more, it was impossible for people to afford higher bills. Most residents also protested about exorbitant water rates - people who had formerly paid less than Rs.100 a month for water were now receiving bills of Rs.1500, and in some cases, even more than Rs. 4,000 a month; this was a vast economic dispute for low-income dwellers to dissatisfy the vertical living. The Rs.1,000,000 that families were required to pay in advance took much effort to get the keys to their apartment. The most common means of most households and the most often had to borrow the funds quickly or pawn collateral at a high-interest rate. Therefore, the response rate presented as $62 \%$ or higher value related to the financial security and loan facility. Finally, issues related to other assets such as television, radio, refrigerators, etc., buying those fixed assets has discouraged new settlements due to the high cost of other basic daily housing requirements. It presented as $54 \%$, which rate is low while comparing the other economic issues.

\section{Architectural, planning, and technical}

In the past, governments also considered physical improvements to living space, assuming that this would change urban poor people's living conditions and social lives. As per the professionals' views, the findings presented the criteria of recreational and landscaping, elevator design, and quality housing design from $90 \%, 80 \%$, and $70 \%$, respectively, highly affected to architectural, planning, and technical. Accordingly, Randiya Uyana project planners claimed that recreational and landscaping and quality housing design are essential to upgrade low-income peoples' quality living standards and mental satisfaction to well-being. However, it is the primary challenge because the financial restriction and return on investment are very low in the social housing projects. Thus, the criteria of the number of rooms, floor area, site location, and expansion of the unit are $30 \%, 20 \%, 20 \%$, and $10 \%$, respectively (refer to figure 9), with significantly lower rates from professionals' views. The explanations can be further deliberated as the minimum unit size is 450 square feet if tenants do not have enough space for their entire families and belongings. It is, nonetheless, an improvement over the family's previous slum housing, which most likely consisted of less than 450 square feet with none of the amenities. Despite the positive professionals' views for this matter, the residents' view is different while showing negative and high rate for the criteria of many rooms, floor area, location of the site, and expansion of the unit such as $82 \%, 77 \%, 88 \%$, and $70 \%$ respectively. From the community views, most of those who moved had houses that were twice as big as the new apartments, if not larger, and a significant percentage of them lived in houses with several floors.

Further, URP's policy is an apartment for a house, not an apartment for a household, because if many families were living in the same house, the policy was not changed. Aside from not getting enough room for their possessions, another major issue over a shortage of space is the lack of space for cultural rites and ceremonies at holidays or even when a funeral. Accordingly, aforesaid critical opinions have arisen from civil society and experts while investigating architectural, planning, and technical issues. 




Source: Survey Data, 2021

Figure 9. Nature of the Architectural, Planning and Technical Issues in Resettlement Housing

\section{Management and operational}

High-rise living typically contains many utilities and services, such as public squares, elevators, and electricity and water supply. Still, there is no specific division of responsibility for the building's proper management and operation. In this study, management and the operational issue are mainly considered from the professionals' views under the five main criteria viz., public spaces, electricity and water network, solid waste, corridors and elevators and cost of management of the entire building, the rates indicated as 70\%, 80\%, 60\%, 80\%, and 70\% respectively (Refer figure 10).

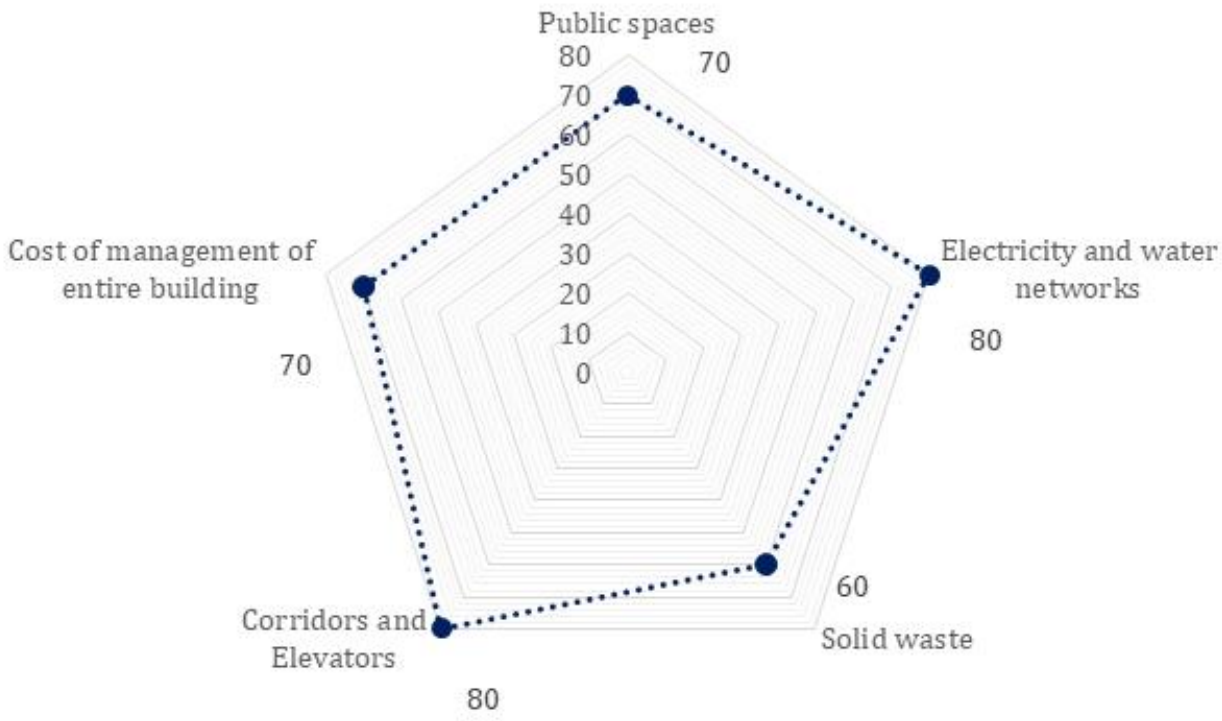

Source: Survey Data, 2021

Figure 10. Nature of the Management and Operational Issues in Resettlement Housing 
Amongst crucial issues have been demonstrated from the electricity and water network and corridors and elevators. The difficulties in collecting bills from low-income residents resulted in the inability to pay the bills on time to the NWS\&DB and CEB. Thus, lack of management and maintenances of the lifts and corridors, etc., were significant issues to a deterioration in the quality of the building and community. Therefore, establishing a management corporation is essential for the building's management and upkeep. The maintenance body must have enough funds to maintain the building in good condition.

As presented in figure 11, the social, cultural, and economic issues are the main postimplementation issues in the Randiya Uyana pro, representing 28\% and 27\%. Management, operational and architectural planning, and techniques are more decisive; however, social and economic issues are more critical in this context (Sri Lankan). This situation is typical for other Asian and African low-income housing projects. As mentioned in the literature, Kibera lowincome housing project in Africa has confronted many social, cultural, and economic issues other than the issues of management, operational, architecture, planning, and design (Amnesty International, 2009; Mitra, et al., 2017; Fernandez \& Calas, 2019; Agayi \& Sag, 2020). And Chennai India (Jayaseelan \& Premraj, 2014; Diwakar \& Peter, 2016), Guangzhou, China (Chen, et al., 2020; Gu \& Zhang, 2020), Wan Chai District, Hong Kong (Han, 2018), etc. Thus, as mentioned in literature Pruitt-Igoe public housing complex in St Louis, Missouri, is one of the most prestigious public housing developments in the United States, which widely focused on architectural, planning, and technical issues of urban regeneration projects (Bristol, 1991; O'Neil, 2007; Samaratunga \& Hare, 2012).

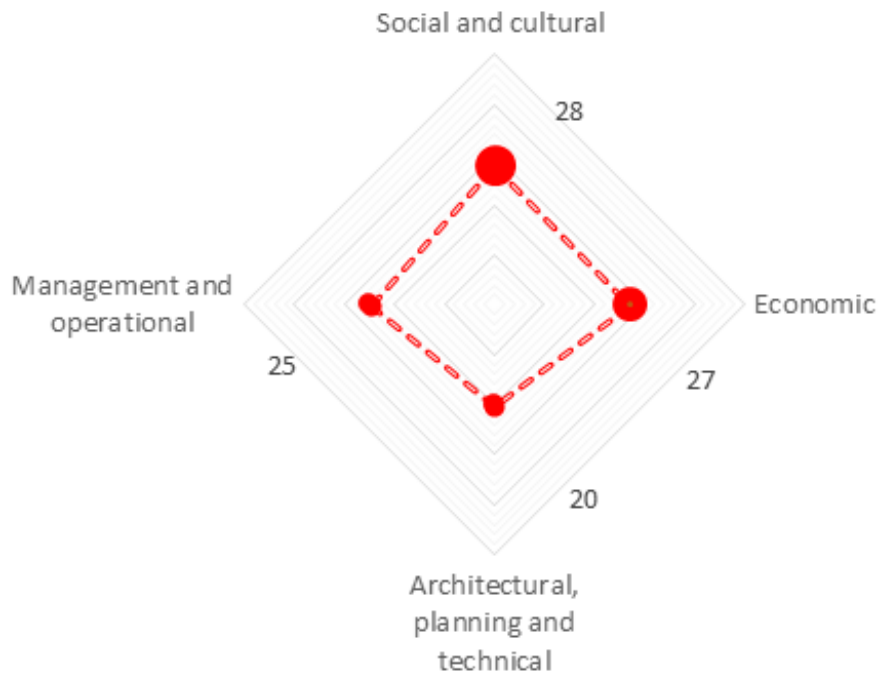

Source: Survey Data, 2021

Figure 11. Nature of the post-implementation issues of Randiya Uyana re-settlement housing.

Resolution framework to minimize the post-implementation issues in the urban regeneration project

The resolution framework provides the solutions from assessing current issues of Randuya Uyana low-income housing project in Colombo, Sri Lanka. 
- The National Involuntary Resettlement Policy's Legal Guidelines must be revised and kept up to date with national and international norms to be enshrined in legislation, making it open to all subsequent land purchases that require relocation.

- Each household must sign a legally binding contract as they move into their new apartments. All state institutions, banks, colleges, and foreign works must accept this text, available in Sinhala and Tamil.

- To eliminate the urban poor's housing crisis, consider all alternatives, including in-situ regeneration and upgrading. Involuntary relocation should be avoided as far as possible, and this also involves looking at low-rise residential buildings rather than high-rise projects, which are far more challenging to transition to and maintain in the long run. If high-rise structures are the only option for URP, a participatory building design strategy with the relevant groups is proposed to explain how the complexes and apartment layout can be achieved.

- Financial assistance is required for programs, especially in the provision of utility to improve living conditions. Participation of the urban poor in housing provision is a good initiative. Still, other stakeholders must be brought in to help the poor realize their hopes of living in Colombo.

- The UDA has to look at ways to make residential buildings more energy-efficient and affordable. For instance, the green spaces and residents would save money on monthly management expenses if the elevators were powered by solar electricity. Thus alternative energy efficiency methods require to be introduced to the dwellers to saving their monthly high electricity bills.

- Building architecture should be reconsidered in light of the current issues that have arisen due to design elements. Accordingly, provide innovative design solutions. For instance, it will provide a more communal environment if residents allocate rooftops for home gardens and children's play areas.

\section{Conclusion}

This article focused on the post-implementation issues of the Colombo urban regeneration project to develop a resolution framework. To explain the lessons and major-related issues of urban regeneration projects such as social and cultural, economic, architectural, planning and technical, management, and operational that can help develop the resolution model, the study uses three similar cases: Pruitt-Igoe, Chennai, and Kibera. Thus 22 criteria of each issue were identified from the comprehensive literature review. The findings suggested that the social, cultural, and economic disputes of low-income housing projects were very apparent in all Asian and African cases, similar to the Randiya Uyana low-income housing project in Sri Lanka. The study's aim is not to improve local social and economic growth per se; instead, this is supposed to manifest the long-term.

\section{Acknowledgement}

We would like to thank the Centre for Real Estate Studies (CRES), Department of Estate Management and Valuation, University of Sri Jayewardenepura. 


\section{References}

Agayi, C. O., \& Sag, N. S. (2020). An Evaluation of Urban Regeneration Efforts in Kibera, Kenya through Slum Upgrading. International Design and Art Journal, 2(2), 176-192.

Amnesty International. (2009). Kenya: The unseen majority Nairobi's two million slum-dwellers, s.l.: Amnesty International.

Average, C. (2019). Low-income housing problems and low-income housing solutions: opportunities and challenges in Bulawayo. Journal of Housing and the Built Environment, 34, 927-938.

Bah E.M., Faye I., Geh ZF (2018) Slum Upgrading and Housing Alternatives for the Poor. In: Housing Market Dynamics in Africa. Palgrave Macmillan, London. https://doi.org/10.1057/978-1-137-59792-2_6

Bristol, K. G., (1991). The Pruitt-Igoe Myth. Journal of Architectural, 163-171.

Chen, X., Zhu, H., \& Yuan, Z., (2020). Contested memory amidst rapid urban transition: The cultural politics of urban regeneration in Guangzhou, China. Cities, 102(0264-2751), 1-11.

Calderon, C. (2008). Learning from Slum Upgrading and Participation: A case study of participatory slum upgrading in the emergence of new governance in the city of MedellínColombia (Dissertation). Retrieved from http://urn.kb.se/resolve?urn=urn: nbn:se:kth:diva-9616

Cohn, R. (1985). Investigating public housing in America, New York: High-Rise Hell.

Diwakar, G. D., \& Peter, V. (2016). Re-settlement of Urban Poor in Chennai, Tamil Nadu: Concerns in R\&R Policy and Urban Housing Programme. Journal of Land and Rural Studies, 4, 97-110.

Fernandez, R. A. F., \& Calas, B. (2019). The Kibera Soweto East Project in Nairobi. Les Cahiers d'Afrique de l'Est / The East African Review, 44,2011, 129-145.

Gu, Z., \& Zhang, X. (2020). Framing social sustainability and justice claims in urban regeneration: A comparative analysis of two cases in Guangzhou. Land Use Policy, 102(0264-8377), 19 .

Han, K. L., (2018). Urban Renewal and Gentrification in Hong Kong: A Case Study of the Wan Chai District, Hong Kong: Department of social sciences, The Education University of Hong Kong.

Jayaseelan, N. J., \& Premraj, F. C. (2014). The sad story of slum people in re-settlement coloniesdocumentations from focus group discussion. Indian Journal of Applied Research, 4(12).

Kolodny, R., Baron, R. D., \& Struyk, R. J. (1983). The insider's guide to managing public housing. US Department of Housing and Urban Development.

Mitra, S., Mulligan, J., Schilling, J., Harper, J., Vivekananda, J., \& Krause, L. (2017). Developing risk or resilience? Effects of slum upgrading on the social contract and social cohesion in Kibera, Nairobi. Environment \& Urbanisation, 29(1), 103-122.

Mullins, P., Western, J., \& Broadbent, B. (2001). The links between housing and nine key sociocultural factors: A review of the evidence positioning paper. Australian Housing and Urban Research Institute.

O'Neil, T. (2007). Pruitt and Igoe started strong, but in the end, failed. [Online]. Retrieved from: http://www.stltoday.com

Roberts, P., \& Sykes, H. (2000). Urban Regeneration: A Handbook. London: London: British Urban Regeneration Association. 
Saccomani, S. (2016). Urban regeneration and crisis. EURA Conference, City lights Cities and citizens within/beyond/notwithstanding the crisis, 16-18 June 2016 Track 3, "Governing cities: Stressed institutions and new shapes of urban democracy" At Torino, Italy.

Samaratunga, T., \& Hare, D. O. (2012). High-Density high rise vertical living for low-income people in Colombo, Sri Lanka: Learning from Pruitt-Igoe. Architecture Research, 2(6), 128-133.

Soureshjani, M. H., \& Soureshjani, K. (2016). A Big Lost Fragment; Evaluating Socio-cultural Considerations in Mehr Housing Project, Case Study Analysis of Manzarieh. Journal of Civil \& Environmental Engineering, 6(6), 1-6.

Stanley, J. (2004). Development Induced Displacement and Resettlement. Forced Migration Online.

Tilabi, S., Takala, J., Forss, T., Jieming, L., Sishi, L., \& Mądra-Sawicka, M. (2017). Operational Performance of Affordable Housing Projects. MIC 2017: Managing the Global Economy; Proceedings of the Joint International Conference, Monastier di Treviso, Italy, 24-27 May 2017. University of Primorska Press.

UDA, 2019. Colombo Urban Regeneration Project, s.l.: Asian Infrastructure Investment Bank.

Willemsen, E. J. W. (1992). Slum re-settlement: Increasing residential stability for the urban poor? : a study on the eviction and resettlement of slum communities in Bangkok, in comparison with international guidelines. Master Thesis. The Eindhoven University of Technology.

Wijayasinghe, SLDK (2010). Factors contributing to the failure of development-induced resettlement projects: A case study of the Sahaspura slum relocation project, Colombo, Sri Lanka. Retrieved from http://hdl.handle.net/2105/11586 